\title{
The Proposed EU Human Rights Sanctions Regime
}

\section{A First Appreciation}

\author{
Nienke van der Have \\ Senior Legal Specialist; the Ministry of Interior and Kingdom Relations, \\ Department of Constitutional Affairs and Legislation, The Hague, \\ the Netherlands \\ nienkevdhave@hotmail.com;nienke.have@minbzk.nl
}

\begin{abstract}
The initiative for a European Union (EU) human rights sanctions regime that targets individual human rights offenders builds upon an interesting trend set by the United States' Magnitsky Act. It has the potential to contribute to the development of international law and allow states and the EU to take on a more progressive attitude in relation to gross human rights violations committed worldwide. As an EU-wide initiative, it also has the opportunity to break with the muddled past and set a positive example. To do so, there are several important factors to consider related to the conceptual aim of the regime, its demarcation and potential effectiveness in practice.
\end{abstract}

\section{Keywords}

Sanctions - individual sanctions - European Union - human rights - gross human rights violations - Magnitsky Act 
Towards the end of 2018, the Netherlands initiated discussions on a possible European Union (EU) human rights sanctions regime. ${ }^{1}$ A conference was held on the 2oth of November 2018 in the Peace Palace in The Hague, where representatives gathered to discuss the initiative of all (then) $28 \mathrm{EU}$ member states, other states that have human rights sanctions regimes or have an interest in them, academics and civil society stakeholders. The concept has since been introduced for discussion in Working Party meetings of the Council. ${ }^{2}$ In March 2019, the European Parliament (EP) adopted a resolution with 447 to 70 calling for the adoption of an EU human rights sanctions regime. ${ }^{3}$

Finally, in December 2019, foreign ministers of the EU Member States embraced the initiative with strong consensus, which led the European External Action service to commence with the preparatory work towards legislation. ${ }^{4}$ The exact focus of the proposed sanctions regime is still undetermined, but the proposal concentrates on combating gross human rights violations by imposing sanctions on individuals believed to be involved in these violations. ${ }^{5}$ An informal paper by the Dutch administration argued that "[b]y placing such individuals and their crimes in the limelight, these sanctions would put a price on committing gross human rights violations and abuses, [and] function as a deterrent." ${ }^{\prime \prime}$ The scope of the proposed sanctions regime is intended to be global, meaning the alleged violations and the targeted individual(s) could be situated anywhere in the world.

* The views, information, or opinions expressed do not represent those of any institution to which the author has been or is currently affiliated.

1 A. Rettman, 'Dutch flesh out proposal for EU human rights sanctions', EU Observer, 19 November 2018, available at: https://euobserver.com/foreign/143424.

2 A. Rettman, 'Ball rolling on EU human rights sanctions', EU Observer, 1 March 2019, available at: https://euobserver.com/foreign/144308.

3 European Parliament resolution of 14 March 2019 on a European human rights violations sanctions regime (2019/258o(RSP)), available at: http://www.europarl.europa.eu/doceo/ document/TA-8-2019-0215_EN.html.

4 Barigazzi, Jacopo, 'EU to prepare Magnitsky-style human rights sanctions regime', Politico, 9 December 2019, available at: https://www.politico.eu/article/eu-to-prepare-magnitsky-style -human-rights-sanctions-regime/.

5 Human rights obligations are targeted at states and therefore only states can commit gross human rights violations. For individuals, the term 'human rights abuses' is more appropriate and is used in this article when mainly discussing the acts of individuals.

6 A. Rettman, 'Dutch to host EU talks on human rights sanctions', EU Observer, 5 October 2018, available at: https://euobserver.com/foreign/143040. 
The initiative is commendable in its ambition. Nevertheless, it leaves conceptual, legal and practical questions unanswered. First, there is conceptual confusion about whether the regime will have a deterrent and/or punitive aim. Second, it is unclear for which human rights violations sanctions should be imposed. Third, there are reasons to question the effectiveness of human rights sanctions regimes in practice. This article will explore these three issues, thereby offering a first appreciation of the initiative and perhaps contributing to its further understanding and development. ${ }^{7}$

There is a distinction between geographical/state versus targeted/individual sanctions. When put in historical context, a shift can be observed from the former to the latter type. Imposing state sanctions to address human rights violations has a long and muddled history. Focusing on the post-second world war era, state sanctions have been used as a political tool by many states and International Organizations (IOs) such as the United Nations (UN) to try and induce changes of behavior. For example, trade and arms embargoes have been imposed on states in reaction to invasions of other territories or reports about the development of nuclear weapons. ${ }^{8}$ These broad types of sanctions are still applied, but have become disputed for the unintended effects they can have on the human rights of innocent bystanders.

Although more targeted or individual sanctions were already possible under some of the general sanctions regimes and widely applied in the context of counter-terrorism, the first sanctions regime used solely to target individuals who commit human rights abuses abroad was introduced in the United States (US) with the Sergei Magnitsky Rule of Law Accountability Act in 2012. ${ }^{9}$ This regime was called into existence after the death of Russian whistleblower Sergei Magnitsky, who uncovered a deep-rooted web of corruption and died

7 An issue that will not be dealt with in this article, but is nevertheless relevant, is related to the question how sanctions that target individuals who are also state officials tie in with the rules on diplomatic immunities and state responsibility.

8 S.P. Marks, 'Economic Sanctions as Human Rights Violations: Reconciling Political and Public Health Imperatives', Am J Public Health (1999)89/10, 1509-13.

9 T. Firestone, and K. Contini, 'The Global Magnitsky Act', Criminal Law Forum (2018)29, 617-28; Magnitsky Act, 14 December 2012, Public law 112-208, title IV, 22 USC 5811, available at: https://www.treasury.gov/resource-center/sanctions/Programs/Documents/pl112_208 .pdf. 
under suspicious circumstances in 2009 while he was imprisoned in Russia. ${ }^{10}$ The first Magnitsky Act was focused on individuals in Russia believed to be involved in Magnitsky's death and currently targets around 5o Russian officials. ${ }^{11}$ Given its focus on Russian officials, the first Act was ultimately disparaged as being politically motivated and the US Government proceeded to adopt a Global Magnitsky Act in 2016. ${ }^{12}$ This Global Magnitsky Act expanded upon the first Magnitsky Act both in substance and geographical scope. It provided the US government with tools to impose sanctions on individuals globally for involvement in gross human rights violations or corruption. ${ }^{13}$

Since the Global Magnitsky Act was adopted in the US, other states have followed suit. The following states have also adopted human rights sanctions regimes based on the example of the Magnitsky act (listed chronologically): Estonia, ${ }^{14}$ Canada, ${ }^{15}$ Lithuania, ${ }^{16}$ Latvia ${ }^{17}$ and the United Kingdom. ${ }^{18}$ Sanctions imposed under these laws can take the form of, for example, the freezing of assets, travel/entry bans, forfeiture of money and/or property and the disclosure of information. ${ }^{19}$ This year, the Parliamentary Assembly of the Council

10 A. Horton, 'The Magnitsky Act, Explained', Washington Post, 14 July 2017, available at: https://www.washingtonpost.com/news/the-fix/wp/2017/07/14/the-magnitsky-actexplained/?noredirect=on\&utm_term $=.4$ bfino8dbbf8.

11 Lists are available at: https://www.treasury.gov/resource-center/sanctions/OFAC-Enforce ment/Pages/20130412.aspx; https:/www.treasury.gov/resource-center/sanctions/OFAC -Enforcement/Pages/20141229.aspx; https://www.treasury.gov/resource-center/sanc tions/OFAC-Enforcement/Pages/20160201.aspx; https://www.treasury.gov/resource-cen ter/sanctions/OFAC-Enforcement/Pages/20171220_33.aspx.

12 Global Magnitsky Human Rights Accountability Act, S284, 18 May 2016, available at: https:// www.congress.gov/bill/114th-congress/senate-bill/284/text/es.

13 Firestone and Contini (n 9).

14 A. Rettman, 'Estonia joins US in passing Magnitsky law', EU Observer, 9 December 2016, available at: https://euobserver.com/foreign/136217.

15 Justice for Victims of Corrupt Foreign Officials Act (Sergei Magnitsky Law), S.C. 2017, c. 21, 18 October 2017, available at: https://laws.justice.gc.ca/eng/acts/J-2.3/page-1.html.

16 R. Picard, 'Lithuania: Parliament Adopts Version of Magnitsky Act', OccRP, 16 November 2017, available at: https://www.occrp.org/en/27-ccwatch/cc-watch-briefs/7265-lithuaniaparliament-adopts-version-of-magnitsky-act.

17 S. Carolan, 'Latvia Becomes Final Baltic State to Pass Magnitsky Law', occRP, 9 February 2018, available at: https://www.occrp.org/en/daily/7621-latvia-becomes-final-balticstate-to-pass-magnitsky-law.

18 Criminal finances act 2017, (c.22), 27 April 2017, available at: http://www.legislation.gov.uk/ ukpga/2017/22/section/13/enacted: amendment of the Proceeds of Crime Act 2002, dealing with terrorist property and tax evasion.

19 C. Portela, 'Targeted Sanctions Against Individuals on Grounds of Grave Human Rights Violations - Impact, Trends and Prospects at EU Level', Study for the European Parliament, PE603.869, 26 April 2018, available at: http://www.europarl.europa.eu/thinktank/ 
of Europe called upon member states to "consider enacting legal instruments enabling their government to impose targeted sanctions on individuals reasonably believed to be personally responsible for serious human rights violations for which they enjoy impunity on political or corrupt grounds." ${ }^{20}$ In other parts of the world, states are also considering the potential of human rights sanctions regimes targeted at individuals. For example, Australia and Japan took part in the conference in The Hague as interested parties. In other words, human rights sanctions regimes aimed at individuals are becoming somewhat of a trend.

\section{3}

\section{Critical Analysis}

This section will critically analyze the notion of individual human rights sanctions regimes from three perspectives. The first is the conceptual confusion surrounding the aim of imposing individual sanctions on human rights offenders, the second is the legal demarcation of gross human rights violations and the third is the effectiveness of imposing individual sanctions in practice. Based on this analysis, several lessons will be drawn that could inform the design of the proposed EU human rights sanctions regime.

\subsection{Conceptual Confusion: Punishment or Prevention}

The Committee on Legal Affairs and Human Rights of the Council of Europe has noted that "it is still being debated whether [targeted] sanctions have a criminal, administrative or civil character". ${ }^{21}$ The confusion seems to stem in part from the evolution from state sanctions to more targeted or individual sanctions. State sanctions have generally been denied a punitive character, which may be connected to the controversy surrounding the notion of a form of criminal responsibility of states. ${ }^{22}$ In the case of individuals, however, prevention and punishment are more intricately linked. These sanctions are intended

en/document.html?reference=EXPO_STU\%282018\%29603869, pp. 7-9 and 24-25: Contains a more in-depth exploration of the definition and form of sanctions and an overview of the focus of the Magnitsky Acts adopted up until Lithuania in 2017.

20 Parliamentary Assembly of the Council of Europe, 'Sergei Magnitsky and beyond fighting impunity by targeted sanctions', Resolution 2252 (2019), available at: http:// www.europarl.europa.eu/cmsdata/161079/6\%20-\%2006\%2oResolution\%20COE\%2oSer gei\%2oMagnitsky.pdf.

21 Committee on Legal Affairs and Human Rights of the Council of Europe, 'United Nations Security Council and European Union Blacklists', Report for the Parliamentary Assembly, Doc 11454, 16 November 2007, available at: https://assembly.coe.int/nw/xml/XRef/X2HXref-ViewHTML.asp?FileID=11749, para 4.

G. Gilbert, 'The Criminal Responsibility of States', 39(2) Int. and Comp. Law Quart. 345. 
to restrict targeted individuals in certain areas of their life, which almost per definition has a negative effect on their human rights and will likely be experienced as a form of punishment.Punishment is in itself a widely-acknowledged form of prevention, both in a general and specific sense. General, because the mere formulation of a rule with a form of punishment attached is assumed to deter individuals from breaking the rule. ${ }^{23}$ Specific, because punishment of an individual who breaks the rule can prevent that person from continuing to break the rule. Both elements of punishment and prevention play a role in individual sanctions regimes and can even been seen as going hand in hand. The fact that individual sanctions have both preventive and punitive aspects has implications for the way a regime is designed, both in the area of protecting targeted individuals' rights and how the regime is institutionally and legally embedded.

First of all, it is important to acknowledge that individual sanctions per definition carry the potential to violate certain rights of targeted individuals, such as the right to property, privacy or freedom of movement. This is a matter that has already been dealt with extensively in the context of sanctions imposed on terrorist suspects. For example, individual sanctions imposed on terrorist suspects by the EU have been said to "compromis[e] the very core of procedural and judicial protection" of human rights, for example because of insufficient access to information and lack of an effective right of defence. ${ }^{24}$ Drawing the focus away from the punitive aspect of sanctions could have the - perhaps subtle - effect of attaching less importance to safeguards for targeted individuals. In national law systems, whether or not sanctions are considered a form of punishment typically has repercussions for the safeguards surrounding such measures. Without sufficient safeguards, the framework would be open to (political) abuse and could give rise to new human rights violations. Needless to say, this would utterly undermine its trustworthiness. Similarly, it has been noted that arbitrary and inconsistent listing practices would quickly endanger the credibility of a regime. ${ }^{25}$

The Dutch Minister of Foreign Affairs, when reporting on the conference held in The Hague, specifically mentioned the importance of due process for

23 J. Andenaes, 'The General Preventive Effects of Punishment' (1966) 114(7) UPaLRev 949, 952-4: Andenaes describes the belief in general prevention as mostly an ideological conviction, while there is a lack of empirical research that can prove it. Although progress has been made in terms of research, generally this still seems to be the case today.

24 C. Eckes, EU Counter-Terrorist Policies and Fundamental Rights: The Case of Individual Sanctions (OUP, 2010).

Portela (n 19) pp. 27-29. 
listing, review and de-listing. ${ }^{26}$ The $\mathrm{EP}$, in its resolution calling for the adoption of an EU individual sanctions regime, "insists [...] that decisions to list and delist individuals or entities should be based on clear, transparent and distinct criteria [...] in order to guarantee a thorough judicial review and redress rights." 27 This is a good start. However, for safeguards to truly receive the attention they deserve, the punitive aspect of a possible EU individual sanctions regime should be explicitly recognized in the negotiation process. For example, an aspect that has so far received too little attention is how the standards of proof for the imposition of global sanctions need to account for the geographical distance and dependency on more indirect sources of information than in cases where the alleged acts take place within state territory. ${ }^{28}$ This is a very serious challenge in the context of global individual sanctions and is directly linked to due process and the rights of targeted individuals, as a clear standard of proof is a precondition to be able to provide individuals with sufficiently clear information on what basis sanctions have been imposed against them and as a basis for consistent listing practices.

Second, it is important to give proper thought to how a potential EU human rights sanctions regime should be institutionally and legally embedded. Specifically: how will the EU human rights sanctions regime fit within the global legal and institutional background aimed at preventing and punishing gross human rights violations? Under international human rights treaties, state parties are the bearers of multiple obligations to prevent different types of gross human rights violations, both express and implicit, within state territory and extraterritorially. ${ }^{29}$ Such obligations can take the form of short term measures to prevent, but also include an obligation to prosecute and punish wrongdoers to prevent future violations. Most of the obligations in human rights treaties only apply extraterritorially when a state party exercises jurisdiction over territory or individuals abroad. ${ }^{30}$ It is only in the case of torture that states sometimes have an obligation to prosecute and punish individuals who allegedly

26 Brief van de Minister van Buitenlandse Zaken, 'Mensenrechten in het Buitenlands Beleid', Kamerstuk 32 735, no. 229, 26 november 2019, available at: https://zoek.officielebekendmakingen.nl/kst-32735-229.html, p. 3.

27 EP resolution of 14 March 2019 on a European human rights violations sanctions regime (n 3) para 11.

28 Committee on Legal Affairs and Human Rights of the Council of Europe (n 21) para 35; Portela (n 19) pp. 12-13: Notes that the European Court of Justice has so far not clearly specified what standard of proof it will employ to assess whether the reasons to impose sanctions are sufficiently substantiated.

29 N. van der Have, The Prevention of Gross Human Rights Violations Under International Human Rights Law (Asser Press \& Springer, 2018).

Ibid. Chapter 3, p. 96 onwards. 
commit gross human rights violations abroad when that state is not in any way linked to the individual or involved in the events (also known as universal criminal jurisdiction). ${ }^{31}$ Based on the current interpretation of the Genocide Convention by the International Court of Justice, states are not even obligated to prosecute and punish suspects of acts of genocide on any other ground than if the acts took place on their territory. ${ }^{32}$

Against this rather conservative background of state obligations to prosecute and punish gross human rights violations, human rights sanctions regimes that target individuals are a striking development in which states and IOs are developing a legal basis to address human rights violations worldwide. There is a tension between individual sanctions regimes and the principle of state sovereignty, with its element of non-interference in a state's internal affairs. ${ }^{33}$ This begs the question: how will the EU justify imposing sanctions on individuals outside their jurisdiction. ${ }^{34}$ However, if the regime is properly

31 Ibid. p. 163: State parties to the CAT and IACPPT are permitted, but not required, to assume criminal jurisdiction over cases of torture on the basis of the nationality of the victim (passive personality principle). State parties to both treaties are required to assume criminal jurisdiction based on the nationality of the accused (active personality principle) and when an individual suspected of having committed acts of torture abroad is present "in any territory under the jurisdiction of a State party" (universal criminal jurisdiction); Convention against Torture and other Cruel, Inhuman or Degrading Treatment or Punishment (adopted 10 December 1984, entered into force 26 June 1987) 1465 UNTS 85 (CAT) art. 5(1)c; Inter-American Convention to Prevent and Punish Torture (adopted 9 December 1985, entered into force 28 February 1987) OAS TS 67 (IACPPT), art. 12C; I. Bantekas, 'Criminal Jurisdiction of States under International Law', MPEPIL, March 2011, available at: http://opil.ouplaw.com/view/10.1093/law:epil/978019923169o/law-978019923169o-e10 21?rskey=v8P17C\&result=1\&prd=EPIL, para 28 : It is considered customary international law that states that are not party to the CAT or IACPPT are permitted to assume universal jurisdiction over suspects of torture. Convention for the Prevention and Punishment of the Crime of Genocide (adopted 9 December 1948, entered into force 12 January 1951) 78 UnTS 277 (Genocide Convention), art. 6; Application of the Convention on the Prevention and Punishment of the Crime of Genocide (Bosnia and Herzegovina v. Serbia and Montenegro) (Merits) [2007] ICJ Rep 2, para 184 and 442: There is permissive universal criminal jurisdiction for acts of genocide, but it is not an obligation for states party to the Genocide Convention.

33 Van der Have (n 29) p. 122: States have limited legislative and enforcement jurisdiction abroad.

34 Case T-315/01, Yassin Abdullah Kadiv Council and Commission [2005] ECR II-3649: In the Kadi case, the European Court of Justice held that the joint legal basis of art. 6o, 301 and $308 \mathrm{EC}$ was sufficient for the EU to have the competence to create a regime to impose individual sanctions on terrorist suspects; Eckes (n 24) Chpt. 2: In contrast to the Kadi case, Eckes argues that the EU does not currently have the legal competence to impose individual sanctions on people in third countries. 
embedded within the current legal landscape, individual sanctions have the potential to greatly contribute to the progressive development of international law in this area. For example, the International Law Commission's Articles on State Responsibility contain a developing obligation for states to cooperate to bring to an end serious violations of peremptory norms. ${ }^{35}$ Imposing sanctions on individual human rights abusers could be a means to an end and become a source of inspiration for the types of measures states may (be required to) take in that context. ${ }^{36}$ Furthermore, they may push for a more progressive understanding of the geographical scope of the obligation to prevent and punish genocide or other gross human rights violations.

In terms of the institutional background, the regime was proposed primarily against the backdrop of the fight against impunity and is said to complement geographical regimes and international criminal law. ${ }^{37}$ This again underlines the dual aim of inducing changes in the behavior of individuals to deter (further) human rights abuses, but also holding individuals accountable who might otherwise go unpunished. As noted above, punishment is often seen as a form of prevention. As a case in point, the preamble of the Rome Statute refers to the International Criminal Court's (ICC) ambition to contribute to the prevention of the most serious crimes of concern to the international community as a whole. ${ }^{38}$ Broader use of individual sanctions increases the potential for overlap with the ICC's mandate, which brings along the potential of duplicity and raises a need for cooperation. ${ }^{39}$ The EP has stressed in its resolution calling for an individual sanctions regime "that the criminal prosecution of the perpetrators of gross human rights violations and atrocity crimes through domestic or international jurisdictions should remain the primary objective of all efforts undertaken by the EU and its Member States to combat impunity." ${ }^{20}$ This further underlines the need for cooperation with

35 International Law Commission, Draft Articles on Responsibility of States for Internationally Wrongful Acts with Commentaries (November 2001) UN GAOR Suppl No 10 (A/56/10) chpIVE1, art 41(1).

$36 \quad$ Van der Have (n 29) p. 167.

37 Rettman (n 1$)$.

38 Rome Statute of the International Criminal Court (adopted 17 July 1998, entered into force 1 July 2002) 2187 UNTS 3 (Rome Statute) preamble and art. 5 .

39 K. Boon, 'Jurisdictional Overlap: Security Council Sanctions and the ICC', Opinio Juris, 25 July 2014, available at: http://opiniojuris.org/2014/07/25/jurisdictional-overlap-securitycouncil-sanctions-icc/; L. van den Herik, 'Peripheral Hegemony in the Quest to Ensure Security Council Accountability For its Individualized UN Sanctions Regimes', (2014) J Confl Stud 9(3):427.

40 EP resolution of 14 March 2019 on a European human rights violations sanctions regime (n 3) para. 12. 
the ICC in the process of designing an individual sanctions regime and later imposing sanctions. Viewed positively, individual sanctions could perhaps support the ICC's capacity to prosecute suspects by imposing sanctions with the aim of inducing compliance with arrest warrants by limiting a suspect's other options. Moreover, coordination and exchange of information with the ICC could strengthen the amount of proof as a basis for imposing sanctions. At the same time, the punitive effect of sanctions must not go as far as raising the issue of non bis in idem. There is a careful balance to be struck.

If the deterrent aim of sanctions regimes is to be taken seriously, however, there is a much broader legal and institutional background to consider than international criminal law and the fight against impunity. Several treaties and IOs have established international supervisory/monitoring structures with the aim of deterring gross human rights violations. Examples are the Council of Europe and UN mechanisms for the prevention of torture, which carry out visits to places of detention. ${ }^{41}$ Furthermore, in 2014 the Office for the UN Special Advisers on the Prevention of Genocide and the Responsibility to Protect developed a "Framework of analysis for atrocity crimes: a tool for prevention."42 The framework maps different risk factors for Responsibility to Protect (RtoP) crimes and thereby aims to support prevention strategies. The Office also monitors situations in which these risk factors exist and may lead to atrocity crimes. Against the background of these mandates and the highly relevant work, it would seem advisable for the EU to liaise with the mechanisms for the prevention of torture and the Office for the UN Special Advisers on the development of a possible sanctions regime and to coordinate the application of sanctions with them in the future.

41 European Convention for the Prevention of Torture and Inhuman or Degrading Treatment or Punishment (adopted 26 November 1987, entered into force 1 February 1989) ETS 126, art. 1: In 1987, this treaty established a preventive mechanism authorizing an independent Committee to carry out periodic and ad-hoc visits to places of detention; U. Kriebaum, 'Prevention of Human Rights Violations', (1997) 2(2) ARIEL 155, p. 160 onwards and 188; A. Cassese, 'A New Approach to Human Rights: The European Convention for the Prevention of Torture' (1989) 83(1) AJIL 128: It is considered the first human rights supervisory mechanism with a truly pro-active deterrent focus; Optional Protocol to the Convention against Torture and other Cruel, Inhuman or Degrading Treatment or Punishment (adopted 18 December 2002, entered into force 22 June 2006) 2375 UNTS 237 (CAT Optional Protocol): Based on this model, the Optional Protocol to the CAT introduced a mechanism allowing for visits to places of detention at the universal level in 2002. United Nations Office on Genocide Prevention and the Responsibility to Protect, 'Framework of Analysis for Atrocity Crimes - A Tool for Prevention', United Nations (2014), available at: http://www.un.org/en/preventgenocide/adviser/pdf/framework\%20of\%20 analysis\%2ofor\%2oatrocity\%2ocrimes_en.pdf. 


\subsection{Definitional Issues: What are Gross Human Rights Violations?}

A letter sent to the Dutch Parliament relating the conference held in The Hague describes the question most-discussed as: what are gross human rights violations? ${ }^{43}$ It is a tricky question indeed as it calls for a certain hierarchy, suggesting that some rights are more important than others. This does not sit comfortably with the basic notion that all human rights are interconnected and interdependent. Furthermore, it is unclear whether the violations should be systematic in nature and, if so, what number of violations would qualify as such. In international law and practice, there is no clear-cut definition of gross human rights violations, leaving the matter open to interpretation. The letter describing the conference does not include any description of the substantive discussion on this topic. In any case, no official positions were expressed due to the informal nature of the gathering. Realistically, if the initiative for an EU sanctions regime comes to fruition, the answer to this question will to a large extent be the result of political negotiations. However, this does not and should not preclude the aim of arriving at a clear and legally sound demarcation.

To gain more clarity on the definition of gross human rights violations, it seems logical to first turn to existing individual sanctions regimes. The US Global Magnitsky Act targets individuals who - based on credible evidence are responsible for or involved in (i) extrajudicial killings, torture, or other gross violations of internationally recognized human rights against individuals who have taken on the role of whistleblowers/human rights defenders; (ii) acts of significant corruption; and (iii) forms of assistance to the former two. The acts adopted by the Baltic states, Canada and the UK share a more or less similar focus, although they are applied in different ways and in practice usually have a focus on certain types of violations, sanctions or a certain state or region. ${ }^{44}$ Interestingly, the definition contains both a broadening and a narrowing down of gross human rights violations. First, it is broader because it also covers forms of corruption. Corruption could indirectly lead to gross human rights violations, but is not separately acknowledged as such. Second, the definition has been narrowed down to only cover gross human rights violations committed against whistleblowers and/or human rights defenders. Both are perhaps logical, given the particular background of the Magnitsky Act. However, a new EU human rights sanctions regime does not necessarily have to include these aspects, especially if it wants to make a clean break

43 Brief van de Minister van Buitenlandse Zaken (n 26).

44 Portela (n 19) pp. 24-5: see overview of focus of the different Magnitsky Laws adopted up until Lithuania in 2017; A. Vahtla, 'Estonia Imposes Travel Ban on Individuals on Magnitsky List', ERR, 29 March 2018, available at: https://news.err.ee/692843/ estonia-imposes-entry-ban-on-individuals-on-magnitsky-list. 
with the political controversy surrounding the original Magnitsky Act. Beyond the particular circumstances of Mr. Magnitsky's death and the trend his case has sparked, there is not really any principled reason why gross human rights violations are only worth addressing when committed against whistleblowers and/or human rights defenders. The Dutch initiators have already proposed a broader definition, which could cover sexual violence against women and girls in situations of conflict and the use of famine as a weapon of war.

Looking at the broader international law background, there are a lot of sources that could guide the process of demarcation. First and most importantly, the notion of jus cogens introduces a broadly accepted form of hierarchy among rules of international law. Rules that are considered jus cogens (also known as peremptory rules of international law) cannot be derogated from whatever the circumstances and the rule can only be modified by a subsequent norm that also has a jus cogens character. ${ }^{45}$ The prohibitions of torture, genocide and extrajudicial killings are all considered to have jus cogens status. ${ }^{46}$ Acts of significant corruption, however, are not. Second, there has been increased focus on theories and methods to prevent atrocities. An example is the RtoP, introduced in 2001 by the International Commission on Intervention and State Sovereignty and accepted by the international community of states in the 2005 World Summit Outcome Document. ${ }^{47}$ The RtoP has been a vehicle for the gradual acceptance of international involvement in the reaction to atrocities with a strong focus on prevention and is therefore a relevant source of inspiration. The World Summit Outcome Document specifies the crimes to which the RtoP applies as genocide, war crimes, crimes against humanity and ethnic cleansing. Individual sanctions could strengthen the preventive aspect of the RtoP if human rights violations typically leading to these four crimes are included in the focus. For example, sanctions could be applied when early patterns of gross human rights violations are detected, such as torture and

45 Vienna Convention on the Law of Treaties (adopted 23 May 1969, entered into force 27 January 1980) 1155 UNTS 331, art. 53.

46 Committee Against Torture, 'General Comment 2: Implementation of Article 2 by States Parties', UN Doc CAT/C/GC/2, 24 January 2008, para. 1; Armed Activities on the Territory of the Congo (New Application: 2002) (Democratic Republic of the Congo v. Rwanda) (Jurisdiction and Admissibility, Judgment) [2006] ICJ Rep 6, para. 64; B.G. Ramcharan, The Right to Life in International Law (Martinus Nijhoff Publishers, 1985) 15.

47 Commission on Preventing Deadly Conflict, 'Preventing Deadly Conflict: Final Report with Executive Summary', Carnegie Commission, Washington DC 1997; UN General Assembly Resolution 6o/1, '2005 World Summit Outcome', UN Doc A/RES/6o/1, 24 October 2005, para. 138-9. 
extrajudicial killings, especially when combined with intergroup tensions or when committed against groups protected under the Genocide Convention. ${ }^{48}$

Any demarcation of gross human rights violations potentially carries an element of arbitrariness, especially if developed in an arena of political negotiations. The EU human rights sanctions regime has the opportunity to start with a clean slate and it would therefore be advisable not to simply copy the demarcation in the existing individual sanctions regimes. For example, it would be worth considering not only covering gross human rights violations committed against whistleblowers and/or human rights defenders, but against any individual. Furthermore, it is open to discussion if significant acts of corruption belong in the context of a human rights sanctions regime, or are perhaps better addressed by other means. Finally, it would be wise to base the definition of gross human rights violations on existing rules of international law, if only because it would facilitate the cooperation with institutions mentioned above, such as the ICC and the Office for the UN Special Advisers on the Prevention of Genocide and the Responsibility to Protect.

\subsection{Effectiveness}

Finally, though commendable in ambition, the effectiveness of human rights sanctions regimes aimed at individuals is still an open question. The existing regimes are still relatively young, which makes it difficult to draw any sound conclusions based on the experiences gained so far. In any case, this would require much more in-depth study. ${ }^{49}$ Individual sanctions are more focused than state or geographic sanctions, which may have a host of advantages, such as more direct condemnation of the acts leading to the sanctions and less severe effects on innocent bystanders. ${ }^{50}$ Yet, certain types of criticism related to the effectiveness of state sanctions may still be relevant to consider for individual sanctions regimes. Two particular aspects relating to effectiveness should be kept in mind when developing an individual sanctions regime: (i) the potential for unintended negative effects; (ii) the potential failure to induce changes of behavior. These aspects are especially troublesome when viewed together.

First of all, sanctions imposed on states have been criticized for their unintended negative impact on the enjoyment of human rights by innocent bystanders. ${ }^{51}$ Sanctions have been linked to a deterioration in respect for

48 United Nations Office on Genocide Prevention and the Responsibility to Protect (n 42 ) p. 11.

49 Portela (n 19) p. 19.

$50 \quad$ Portela (n 19) p. 9.

$5^{1}$ D. Peksen, 'Better or worse? The Effect of Economic Sanctions on Human Rights', (2009) 46 J. of Peace Res. 59, p. 77; G. Newbold et. al, 'Weighing Benefits and Costs of 
physical integrity rights and have the potential to undermine economic and social rights like the right to work and/or the availability of food, water, medicines or other basic necessities for people in a targeted state. ${ }^{52}$ They often disproportionately affect vulnerable groups like the poor, women and children, instead of the elites whose behaviors are actually targeted. For example, trade bans are likely to affect the availability of certain products and make them more expensive, which in turn makes it harder for people to buy these products, especially for those with little economic means. People belonging to the elite, however, may be able to circumvent these effects by buying products abroad or because they can simply afford to pay the additional costs. The Committee on Economic Social and Cultural Rights and authors of the Maastricht Principles have both drawn attention to the obligations of parties responsible for imposing sanctions in relation to the human rights of bystanders. ${ }^{53}$ Sanctions imposed on individuals, such as individual travel bans and the freezing of assets, are of course more targeted than economic sanctions applied to states. In that sense, they can be considered a step in the right direction. ${ }^{54}$ However, depending on the position of the targeted individual, the sanctions may still affect a (potentially large) number of bystanders. For example, if a leader of an organization or business is targeted, this will likely affect employees, family members and others who are somehow (economically) dependent upon the targeted individual. ${ }^{55}$ Similar to sanctions imposed on states, this matter should be considered in the way individual sanctions are designed, applied and monitored. ${ }^{56}$

International Sanctions on Iran', Carnegie Endowment for International Peace, 6 December 2012, available at: https://carnegieendowment.org/2012/12/06/weighing-benefits-andcosts-of-international-\%2osanctions-on-iran-event-3884.

52 A. Reinisch, 'Developing Human Rights and Humanitarian Law Accountability of the Security Council for the Imposition of Economic Sanctions', 95(4) AJIL 851; Peksen (n 51). UN Committee on Economic, Social and Cultural Rights, 'General Comment No. 8: The relationship between economic sanctions and respect for economic, social and cultural rights', UN Doc E/C.12/1997/8, 12 December 1997; O. de Schutter et al., 'Commentary to the Maastricht Principles on Extraterritorial Obligations of States in the area of Economic, Social and Cultural Rights' (2012) 34 HRQ 1084 (Maastricht Principles and Commentary), Principle 22.

54 Committee on Legal Affairs and Human Rights of the Council of Europe (n 21) para. 27.

55 Portela (n 19) p. 19: "An examination of UN practice suggests that the level of human rights protection in the target country is more likely to worsen under an episode of targeted sanctions when compared with a situation where sanctions are not imposed, similar to previous findings of studies on comprehensive sanctions."

$5^{6}$ CESCR General Comment 8 (n 53) para. 12-14: Another obligation that could be argued similarly applies is the obligation to respond to the disproportionate suffering of vulnerable groups. 
Second, although sanctions regimes - both those targeted at states or individuals - are built on the belief that sanctions will change behavior, this belief is not always well-founded. In the context of sanctions imposed on states, it has been claimed that the course of events is not significantly altered by the imposition of sanctions. ${ }^{57}$ This is also related to the fact that the sanctions disproportionately affect vulnerable groups, while the elites that are actually targeted find other resources or ways around the sanctions. Again, individual sanctions are more targeted and could potentially be more effective, although their effectiveness has not yet been sufficiently researched. ${ }^{58} \mathrm{~A}$ study carried out for the European Parliament notes: "The political trend towards individualisation observable in sanctions practice has not been matched by an effort to ascertain the efficacy of these measures on the side of the senders. To compound the scarcity of research available on this issue, there is hardly any study that looks specifically at the impact of individual sanctions imposed by the EU, as scholarship focuses mostly on the UN."59 The study also suggests that individual sanctions often lack impact on the targeted individuals and have little effect on their day to day lives. ${ }^{60}$

In the field of criminology, opinions on the preventive effects of forms of punishment vary greatly and suggest that the influence on individual behavior is highly context dependent. The few studies that exist on individual sanctions seem to confirm this image. A recent study on the influence of international sanctions on the decisions of dictators, for example, concluded that their effectiveness depends largely on the ideological determination of the individual targeted ${ }^{61}$ Similarly, a study on the effectiveness of travel and visa bans finds that they are ineffective if the tools are wrongly employed and can even further confirm the loyalty of targeted individuals to their ideology/ political alignment and the behavior it inspires. ${ }^{62}$ If the aim of the proposed EU sanctions regime is indeed to induce changes in behavior and deter further violations, the common-sense assumption that sanctions will have a deterrent

57 T.C. Morgan and V.L. Schwebach, 'Fools Suffer Gladly: The Use of Economic Sanctions in International Crises', (1997) 41 Int. Studies Quart. 45; Marks (n 8) 1510.

$5^{8}$ Portela (n 19) p. 19: "A major research gap exists in the field, as sanctions assessment is routinely conducted with reference to states, despite the existence of an established practice of aiming at individuals often not connected with the states."

59 Ibid. pp. 19-20.

6o Ibid. pp. 26-27.

61 M. Weerdesteijn, The Rationality of Dictators: Towards a More Effective Implementation of the Responsibility to Protect (Intersentia, 2017), pp. 365-74.

62 E. Cosgrove, 'Examining Targeted Sanctions. Are Travel Bans Effective?', in: P. Wallensteen and C. Staibano (eds), International Sanctions: Between words and wars in the global system (Frank Cass, Abingdon, 2005) p. 207. 
effect alone does not suffice. The behavioral effects of sanctions merit more in-depth consideration and research.

\section{$4 \quad$ Conclusion}

The EU human rights sanctions regime builds upon an interesting trend set by the US Magnitsky Act. It has the potential to contribute to the development of international law and allow states and IOs to take a more progressive stand in relation to gross human rights violations committed worldwide. As an EU-wide initiative, it also has the opportunity to set a positive example and break with the muddled and sometimes politically motivated use of sanctions to address human rights violations in the past. To do so, however, there are important and complex factors to consider related to the conceptual aim of the regime, the demarcation of the gross human rights violations and, finally, its effectiveness in practice.

There are two aspects involved in the conceptual aim of the regime: prevention and punishment. Lack of acknowledgement and attention for either one of these aspects could leave the regime open to abuse or not fully embedded within the existing legal and institutional background. First of all, the punitive aspect of applying sanctions to individuals should be explicitly acknowledged. That way, safeguards incorporated in the regime to prevent abuse and protect the rights of targeted individuals, such as a clear standard of proof, will receive the attention they deserve. Second, if the EU human rights sanctions regime wants to live up to its aspiration of deterrence, there is a broader legal and institutional international background to consider. This will ensure that it is properly embedded and makes use of opportunities to exchange information and cooperate.

In relation to the demarcation of gross human rights violations, the $\mathrm{EU}$ human rights sanctions regime could make a clean break with the past by not adopting the, somewhat random, demarcation used in existing regimes but basing its demarcation on existing rules of international law. This would have the added benefit of facilitating cooperation with existing institutions, as mentioned above.

Finally, two aspects deserve particular attention in shaping the EU human rights sanctions regime to ensure its effectiveness in practice. First of all, although the sanctions are targeted at individuals, they may still affect the rights of bystanders who are connected to the targeted individual. These bystander's rights should be considered in the way individual sanctions are designed, applied and monitored. Second, the assumption that sanctions will have a deterrent effect alone is insufficient to be able to legitimize the aim of prevention. The behavioral effect of sanctions therefore merits further research. 